\title{
Pengaruh Faktor Sosiodemografi terhadap Kejadian Lesi Prakanker dengan Skining Inspeksi Visual Asetat (IVA) di Puskesmas Bendo Kecamatan Pare Kabupaten Kediri
}

Wuri Widi Astuti, Reni Yuli Astutik

\begin{abstract}
Abstrak
Kanker serviks adalah salah satu penyebab kematian wanita di dunia. Salah satu metode yang efektif, mudah, murah dan sederhana untuk mendeteksi kanker serviks dini adalah Inspeksi Visual Acetat (IVA). Tujuan penelitian ini adalah menentukan pengaruh faktor sosiodemografi terhadap insidensi lesi prakanker serviks dengan menggunakan pemeriksaan IVA di Puskesmas Bendo Kecamatan Pare Kabupaten Kediri. Desain penelitian menggunakan studi analitik dengan pendekatan cross sectional. Teknik sampling menggunakan simple random sampling dengan jumlah sebanyak 90 responden. Pengumpulan data dilakukan melalui data rekam medik dan wawancara responden. Penelitian ini telah dilakukan pada Oktober 2017 di Puskesmas Bendo Kabupaten Kediri. Data dianalisis menggunakan uji Chi-square dan regresi logistik dengan tingkat signifikansi $\alpha=0,05$. Hasil penelitian menunjukkan ada hubungan yang signifikan pada variabel usia responden $(p=0.013)$, usia pertama berhubungan seksual $(p=0.000)$, pengguna pil KB $(p=0.000)$ dan riwayat kanker dalam keluarga $(p=0.016)$. Variabel paritas dan merokok mempunyai hubungan yang tidak signifikan $(p \geq 0.05)$. Variabel dominan yang terkait dengan lesi prakanker serviks adalah pengguna kontrasepsi $K B$ dengan $O R=18,784$. Disimpulkan bahwa wanita pengguna kontrasepsi oral berisiko 18 kali lebih besar mengalami kejadian lesi prakanker dibandingkan dengan variabel lain. Disarankan kepada bidan dan petugas kesehatan lainnya untuk terus memberikan penyuluhan dan KIE kepada perempuan untuk memeriksakan kesehatan reproduksi secara teratur sebagai pencegahan kanker serviks
\end{abstract}

Kata kunci: faktor sosiodemografi, lesi prakanker, IVA

\begin{abstract}
Cervical cancer is one cause of death of women. The effective, easy, cheap and simple method to detect early cervical cancer is Inspection Visual Acetate (IVA). The objective of this study was to determine the effect of sociodemographic factors on the incidence of cervical precancer lesions by using IVA examination at Bendo Puskesmas Kecamatan Pare Kediri District. The research design was analytical with cross sectional approach. The sampling technique using simple random sampling to get 90 respondents. Data collection was done by using medical record and interview of respondent. This research was conducted in October 2017 at Bendo Community Health Center of Kediri Regency. Data were analyzed by Chi-square and logistic regressi with significance level $\alpha=0,05$. The results showed that there was a significant correlation between respondent age variable $(p=0.013)$, age of first sexual intercourse $(p=0.000)$, pills $(p=0.000)$ and family history of cancer $(p=0.016)$. While the parity and smoking variables have an insignificant relationship $(p \geq 0.05)$. Dominant variables associated with cervical precancer lesions are contraceptive users with $O R=18,784$. It can be concluded that women using oral contraceptives are 18 times more likely to experience precancerous lesions compared with other variables. It is recommended to midwives and other health workers to continue to provide counseling and IEC to women to check reproductive health regularly as prevention of cervical cancer.
\end{abstract}

Keywords: sosiodemografi factors, cervical precancerous lesions, IVA 


\section{PENDAHULUAN}

Kanker serviks merupakan kanker yang disebabkan oleh Human Papiloma Virus (HPV). Virus kanker serviks bersifat spesifik dan hanya tumbuh di dalam sel manusia, terutama pada sel-sel lapisan permukaan/epitel mulut rahim. Ukuran virus HPV sangat kecil, virus ini bisa menular melalui mikro lesi atau sel abnormal di vagina. ${ }^{1}$ Lesi pra kanker adalah kelainan pada epitel serviks akibat perubahan sel-sel epitel, namun kelainannya belum menembus lapisan basal. ${ }^{2}$ Kejadian kanker serviks di Indonesia masih tinggi. Sekitar 52 juta perempuan Indonesia berisiko terkena kanker serviks. Dari seluruh kanker yang terjadi di Indonesia, sekitar $36 \%$ adalah kasus kanker serviks. Wanita yang merokok atau perokok pasif juga meningkatkan risiko kanker serviks. Jumlah pasangan seksual turut berkontribusi dalam penyebaran kanker serviks, semakin banyak jumlah pasangan seksual maka semakin meningkat pula resiko terjadinya kanker serviks, sosial ekonomi yang rendah, lama pengunaan kontrasepsi hormonal dan paritas yang banyak juga menjadi faktor resiko kanker serviks. ${ }^{3}$

Metode skrining yang lazim digunakan di Indonesia adalah skrining yang disebut test pap dan Inspection Visual with Acetic Acid (IVA). Bentuk skrining lainnya adalah Liquid Based Cytology (LBC) dan tes DNA-HPV. ${ }^{4}$ IVA memiliki sensitivitas sampai $96 \%$ dan spesifisitas $97 \%$ untuk program yang dilaksanakan oleh tenaga medis yang terlatih. Hal ini menunjukan bahwa IVA memiliki sensitivitas yang hampir sama dengan sitologi servik sehingga dapat menjadi metode skrining yang efektif pada negara berkembang seperti Indonesia. ${ }^{5}$ Walaupun sudah ada fasilitas yang dapat melayani deteksi dini kanker serviks, namun pelaksanaan skrining ini masih mengalami hambatan diantaranya wanita enggan diperiksa karena ketidaktahuan, rasa malu, rasa takut, dan faktor biaya, sehingga di negara berkembang kanker serviks masih merupakan penyebab kematian terbanyak. Berdasarkan data diatas maka perlu diteliti tentang pengaruh faktor sosiodemografi terhadap kejadian lesi pra kanker serviks dengan skrining Inspeksi Visual Asam Asetat ( IVA ) di Puskesmas Bendo-Pare Kabupaten Kediri.

\section{METODE}

Desain penelitian yang digunakan adalah analitik dengan pendekatan cross sectional. Populasi dalam penelitian ini adalah semua ibu yang melakukan pemeriksaan IVA di puskesmas Bendo sejak bulan Januari-Agustus 2017. Teknik sampling menggunakan simple random sampling untuk mendapatkan sampel sebanyak 90 responden. Pengumpulan data dilakukan dengan menggunakan data rekam medik yang diperoleh dari Puskesmas Bendo untuk melihat hasil dari pemeriksaan IVA dan metode wawancara responden untuk mendapatkan data sosiodemografi responden. Penelitian ini dilakukan pada bulan Oktober 2017 di Puskesmas Bendo Kabupaten Kediri dengan sebelumnya dinyatakan laik etik oleh Komisi Etik Lembaga Penelitian dan Pengabdian Masyarakat STIKES Karya ada Kediri. Kemudian data diolah dan dianalisis secara univariate, bivariate dengan uji statistik chi kuadrat $\left(x^{2}\right)$ dan multivariate menggunakan uji regresi logistik derajat kepercayaan 95\% dan tingkat kemaknaan (alpha) 0,05.

\section{HASIL}

Tabel 1. Distribusi frekuensi kejadian lesi prakanker di Puskesmas Bendo Kecamatan Pare Kabupaten Kediri periode Januari-Agustus 2017

\begin{tabular}{lcc}
\hline \multicolumn{1}{c}{ Variabel } & $\mathbf{f ( n = 9 0 )}$ & $\%$ \\
\hline Kejadian Lesi Prakanker & & \\
Positif & 41 & 45.6 \\
Negatif & 49 & 54.4 \\
\hline
\end{tabular}

Berdasarkan Tabel 1 terlihat distribusi frekuensi kejadian lesi prakanker di Puskesmas Bendo Kabupaten Kediri pada responden yaitu 41 responden (45.6\%) dengan lesi prakanker positif. Sedangkan 49 responden (54.4\%) dengan lesi prakanker negatif. 
Tabel 2. Distribusi frekuensi faktor sosiodemografi responden.

\begin{tabular}{lcc}
\hline \multicolumn{1}{c}{ Variabel } & $\mathbf{f ( n = 9 0 )}$ & $\%$ \\
\hline Usia & 18 & 20 \\
$<35$ tahun & 72 & 80 \\
$\geq 35$ tahun & & \\
\hline Usia Pertama & \\
Berhubungan Seks & 53 & 59 \\
$\geq 20$ tahun & 41 \\
$<20$ tahun & 37 & \\
\hline Pengguna Pil KB & & 75.6 \\
Non Akseptor & 68 & 24.4 \\
Akseptor & 22 & \\
\hline Paritas & & 24.4 \\
$<3$ kali & 22 & 75.6 \\
$\geq 3$ kali & 68 & 91.1 \\
\hline Riwayat Ca & & 8.9 \\
Tidak & 82 & 97.8 \\
Ya & 8 & 2.2 \\
\hline Perokok & 2 & \\
Pasif & & \\
Aktif & & \\
\hline
\end{tabular}

Pada Tabel 2 terlihat distribusi frekuensi faktor sosiodemografi dapat diketahui bahwa sebagian besar responden berusia $\geq 35$ tahun $(80 \%)$, usia pertama kali berhubungan seksual $\geq 20$ tahun (59\%), lama penggunaan pil KB $\leq 5$ tahun (75.6\%), Paritas yaitu melahirkan $\geq 3$ kali $(70 \%)$, Tidak ada riwayat kanker (91.1\%) dan Perokok pasif (97.8\%).

Hasil pada Tabel 3 terlihat hubungan faktor sosiodemografi dengan kejadian lesi prakanker dapat diketahui bahwa terdapat hubungan yang signifikan $(p<0.05)$ antara umur responden, umur pertama kali berhubungan seksual, lama menggunakan pil KB dan riwayat $\mathrm{Ca}$ dalam keluarga dengan kejadian lesi prakanker, edangkan antara paritas dan merokok tidak terdapat hubungan yang signifikan dengan kejadian lesi prakanker $(p \geq 0.05)$.
Tabel 3. Hubungan faktor sosiodemografi dengan kejadian lesi prakanker di Puskesmas Bendo Kecamatan Pare Kabupaten Kediri.

\begin{tabular}{|c|c|c|c|c|}
\hline \multirow[t]{2}{*}{ Variabel } & \multicolumn{2}{|c|}{$\begin{array}{l}\text { Lesi Prakanker } \\
\text { Serviks }\end{array}$} & \multirow[t]{2}{*}{$\begin{array}{c}\text { OR } \\
(95 \% \text { IC) }\end{array}$} & \multirow[t]{2}{*}{ p } \\
\hline & $\begin{array}{l}\text { Negatif } \\
f(n=49)\end{array}$ & $\begin{array}{l}\text { Positif } \\
f(n=41)\end{array}$ & & \\
\hline \multicolumn{5}{|l|}{ Umur } \\
\hline \multicolumn{5}{|l|}{ Responden } \\
\hline a. $<35$ tahun & 15 & 3 & 5.588 & 0.013 \\
\hline b. $\geq 35$ tahun & 34 & 38 & $\begin{array}{l}(1.488- \\
20.985)\end{array}$ & \\
\hline
\end{tabular}

Usia pertama

berhubungan

seksual

\begin{tabular}{lcccc} 
a. $\geq 20$ tahun & & & 12.385 & 0.000 \\
b. $<20$ tahun & 41 & 12 & $(4.497-$ & \\
& 8 & 29 & $34.113)$ & \\
\hline
\end{tabular}

Pengguna pil

$\mathrm{KB}$

\begin{tabular}{|c|c|c|c|}
\hline a. Non & 46 & 22 & 13.242 \\
\hline Akseptor & & & (3.540- \\
\hline b. Akseptor & 3 & 19 & $49.542)$ \\
\hline
\end{tabular}

$\begin{array}{lcccc}\text { a. }<3 \text { kali } & 13 & 9 & 1.284 & 0.079 \\ \text { b. } \geq 3 \text { kali } & 36 & 32 & (0.485- & \\ & & & 3.401) & \end{array}$

Riwayat Ca

$\begin{array}{lllll}\text { a. } \text { Tidak } & 47 & 35 & 4.029 & .0168\end{array}$

b. $\mathrm{Ya} \quad 2 \quad 6 \quad$ (0.767-

21.167)

\section{Merokok}

$\begin{array}{lcccc}\text { a. Pasif } & 49 & 39 & 0.443 & 0.398 \\ \text { b. Aktif } & 0 & 2 & (0.351- & \\ & & & 0560) & \end{array}$

Tabel 4 menunjukkan bahwa variabel yang paling dominan terhadap kejadian lesi prakanker di Puskesmas Bendo Kecamatan Pare Kabupaten Kediri adalah lama penggunaan pil KB dengan prediksi kuat 18 kali $(\mathrm{OR}=18.784)$. 
Tabel 4. Variabel dominan yang berhubungan dengan kejadian lesi prakanker di Puskesmas Bendo Kecamatan Pare Kabupaten Kediri periode JanuariAgustus 2017.

\begin{tabular}{lcc}
\hline \multicolumn{1}{c}{ Variabel } & $\mathbf{p}$ & OR \\
\hline Umur responden & 0.143 & 3.684 \\
\hline $\begin{array}{l}\text { Umur pertama kali berhubungan } \\
\text { seksual }\end{array}$ & 0.000 & 11.773 \\
\hline Pengguna pil KB & & \\
\hline
\end{tabular}

\section{PEMBAHASAN}

\section{Analisis Faktor Sosiodemografi terhadap Kejadian} Lesi Prakanker

\section{- Umur dengan Lesi Prakanker}

Hasil penelitian menunjukkan bahwa pada variabel umur didapatkan $p<0.05$, sehingga dapat disimpulkan bahwa terdapat hubungan yang signifikan antara umur dengan kejadian lesi prakanker. Umur responden yang paling banyak mengalami lesi positif adalah 38 responden dari 41 responden yang positif. Umur merupakan salah satu faktor penyebab lesi prakanker. Wanita yang rentan terkena infeksi HPV adalah wanita dengan rentang usia 25-30 tahun. Namun seiring dengan bertambahnya usia kejadian lesi prakanker semakin meningkat karena resiko infeksi yang menetap dan persisten. Hal ini diduga karena seiring pertambahan usia, perubahan anatomi (retarksi) dan histology (metaplasia) menyebabkan semakin tingginya kejadian lesi prakanker yang apabila dibiarkan dapat berubah menjadi kanker serviks. ${ }^{6}$

\section{- Umur Pertama Kali Berhubungan Seksual dengan Lesi Prakanker}

Umur pertama kali berhubungan seksual mempunyai hubungan yang signifikan terhadap kejadian lesi prakanker dengan $p<0.05$. Hubungan seksual diusia muda sebelum usia 18 tahun beresiko kejadian lesi prakanker lebih tinggi. Hal ini disebabkan karena metaplasia sel skuamosa sangat meningkat pada dewasa muda sehingga risiko terjadinya transformasi atipik skuamosa meningkat yang kemudian menjadi Neoplasia Intraepitel Serviks (NIS) ${ }^{3,7}$
Hasil penelitian menunjukkan bahwa terjadinya lesi prakanker pada wanita yang melakukan hubungan seksual pada usia <20 tahun mempunyai resiko 12 kali lebih besar dibandingkan pada wanita yang melakukan hubungan seksual $>20$ tahun $(\mathrm{OR}=12$. 385). Hal ini sesuai dengan penelitian Rasjidi yang menyatakan bahwa resiko kanker serviks lebih besar 5 kali lipat pada wanita yang melakukan hubungan seksual pada umur $<18$ tahun $^{7}$.

\section{- Pengguna Pil KB dengan Lesi Prakanker}

Menurut beberapa literatur penggunaan pil KB dalam jangka waktu lama yang dihubungkan dengan kejadian lesi prakanker dan kanker serviks menunjukkan hasil yang tidak konsisten. ${ }^{7}$ Beberapa penelitian menunjukkan peningkatan kejadian kanker serviks pada pengguna KB pil. Sehingga masih sangat diperlukan investigasi lebih lanjut mengenai hal ini.

Hasil penelitian ini menunjukkan bahwa pengguna pil KB mempunyai hubungan yang signifikan dengan kejadian lesi prakanker $(p<0.05)$. Hal ini sesuai dengan penelitian sebelumnya yang menyatakan bahwa pengguna kontrasepsi oral dalam melakukan hubungan seksual tanpa menggunakan kontrasepsi tambahan sehingga lebih berisiko terkena virus HPV. Penggunaan pil KB dalam jangka panjang dapat meningkatkan insiden ektropion serviks dan potensi karsinogen lainnya. Estrogen dan progestin juga dapat mempengaruhi sel-sel serviks secara langsung, mempromosikan integrasi DNA HPV ke dalam genom inang, merangsang transkripsi DNA HPV dan meningkatkan proliferasi sel. Steroid seks hormon dapat meningkatkan ekspresi HPV-16 E6 dan Gen E7, dengan inaktivasi dan atau degradasi p53 dan Protein $\mathrm{Rb}$, sehingga menyebabkan kegagalan apoptosis dan peningkatan karsinogenesis. Estradiol dan progesteron adalah imunomodulator dengan efek berbeda pada respon imun pro dan antiinflamasi in vitro dan in vivo. ${ }^{8}$

\section{- Paritas dengan Lesi Prakanker}

Hasil penelitian menunjukkan bahwa variabel paritas dengan $p \geq 0.05$. Artinya bahwa paritas tidak mempunyai hubungan yang signifikan dengan kejadian lesi prakanker, namun hasil Odd Ratio adalah 
1.284 yang menunjukkan bahwa paritas tinggi beriko 1.2 kali lebih besar terjadi lesi prakanker.

Semakin sering seseorang melahirkan semakin besar pula peluang terjadi perlukaan jalan lahir yang memudahkan terjadinya infeksi dari virus HPV yang dapat berkembang menjadi kanker serviks. Tingginya paritas meningkatkan resiko karsinoma serviks karena terjadi transformasi zona eksoserviks untuk beberapa tahun yang memudahkan paparan langsung dari virus HPV dan kofaktor lainnya. ${ }^{9}$

\section{- Riwayat Ca dalam Keluarga}

Riwayat kanker dari keluarga menjadi salah satu faktor penyebab kanker bagi keturunan selanjutnya terutama pada wanita yang mempunyai ibu atau saudara perempuan yang telah menderita kanker serviks sebelumnya. ${ }^{6}$

Hasil penelitian menunjukkan bahwa riwayat kanker dalam keluarga mempunyai hubungan yang signifikan terhadap kejadian lesi prakanker dengan nilai $\mathrm{p}<0.05$. Sekitar $5-10 \%$ kasus kanker memiliki pola keturunan, yang disebabkan oleh mutasi germline pada onkogen dan gen supresor tumor. Kehadiran riwayat keluarga kanker adalah salah satu faktor risiko yang paling penting untuk jenis neoplasia. ${ }^{10}$ Para ilmuwan meyakini bahwa mereka membawa kondisi genetik sehingga membuat lebih rentan terinfeksi HPV. ${ }^{6}$

\section{- Merokok}

Hasil penelitian ini menunjukkan $p \geq 0.05$ dan $\mathrm{OR}=0.443$ yang berarti bahwa tidak terdapat hubungan yang signifikan antara perilaku merokok dengan kejadian lesi prakanker, namun wanita perokok mempunyai resiko 0,.4 kali lebih besar terkena kanker serviks.

Merokok dapat meningkatkan risiko neoplasia melalui beberapa ismebiological. Salah satu mekanisme ini adalah induksi dari efek imunosupresif lokal yang disebabkan oleh metabolit tembakau yang dapat menghasilkan efek adetrimental pada kemampuan inangnya untuk mengembangkan respon imun yang efektif terhadap infeksi virus, meningkatkan risiko infeksi persisten di serviks. Bahan kimia yang ditemukan dalam rokok, seperti nikotin dan metabolit cotinine, yang dapat menyebabkan kerusakan DNA sel-sel epitel squamosa, juga telah ditemukan di lendir serviks perempuan perokok. ${ }^{8}$

\section{SIMPULAN}

Faktor sosiodemografi yang berhubungan terhadap kejadian lesi prakanker dengan signifikan yaitu pada variabel usia responden, usia pertama berhubungan seksual, pengguna pil $\mathrm{KB}$ dan riwayat kanker dalam keluarga. Variabel paritas dan merokok tidak mempunyai hubungan yang signifikan.

Hasil uji multivariat didapatkan variabel dominan yang terkait dengan lesi prakanker serviks adalah pengguna kontrasepsi pil KB.

\section{SARAN}

Disarankan kepada tenaga kesehatan untuk dapat memberikan konseling dan penyuluhan tentang deteksi dini terhadap kejadian kanker serviks melalui pemeriksaan IVA secara rutin sehingga dapat menurunkan angka kematian akibat kanker serviks dengan penanganan yang lebih dini.

\section{DAFTAR PUSTAKA}

1. Samadi, Heru P. Kanker serviks. Jakarta: Tiga Serangkai Pustaka Mandiri; 2010.

2. Departemen Kesehatan RI (DepKes RI). Vaksin HPV untuk perangi kanker serviks. 2007 (diunduh 26 Oktober 2017). Tersedia dari: http://www.depkes.go.id/article/view/873/vaksinhpv-untuk-perangi-kanker-serviks.html

3. Pradipta B, Sungkar S. Penggunaan vaksin human papilloma virus dalam pencegahan kanker serviks. Majalah Kedokteran Indonesia. 2007; 57 (11): 391-6.

4. Nurwijaya H. Cegah dan deteksi kanker serviks. Jakarta: Gramedia; 2010.

5. Wiyono S, Iskandar TM, Suprijono. Inspeksi visual asam asetat (IVA) untuk deteksi dini lesi prakanker serviks. Media Medika Indonesiana. 2008; 43 (3): 116-21. 
6. Wijaya D. Pembunuh ganas itu bernama kanker serviks. Yogyakarta: Sinar Kejora; 2010.

7. Rasjidi I. Deteksi Dini \& Pencegahan Kanker pada Wanita. Jakarta: Sagung Seto; 2009.

8. Gaduci A ,Barsoti C, Coiso S, Domenici L, Genazzani A. Cervical cancer: smoking habit, immune suppresion, oral contaceptive use, and hormone replacement therapy use and cervical carcinogenesis: a review of literature. Gynecological Endocrinology 2. 2011; 7(8): 597 604.
9. Munoz N, Franceschi S, Bosetti C, Moreno V, Herrero R, Smith J. Role of parity and human papilloma virus in cervical cancer: The IARC multicentric case-control study. The Lancet. 2002; 359(9312):1093-101.

10. Campacci N, Lima J,Carvalho A, Michelli R, Haikel $R$, Mauad $E$. Identification of hereditary cancer in the general population: development and validation of a screening questionnaire for obtaining the family history of cancer. Cancer Medicine. 2017; (6): 3014-24. 